\title{
The Nature and Structure of the Islamic World
}

\section{Ralph Braibanti. Chicago: International Strategy and Policy Institute, 1995, $108 \mathrm{pp}$.}

The author offers a concise critique of Westem perceptions of Islam and the Muslim world. He then proceeds to discuss the Muslim world and proposes a taxonomy for it on the basis of certain configurations in order to prove that the Muslim world should not be treated as a monolith. Contemporary problems, which shall be elucidated during the course of this review, are highlighted.

In "Prospectus," Braibanti introduces the perception dialectic that is now prevalent in the West as regards Islam. First, there is the pejorative "green menace," according to which the united hordes of Islam threaten to annihilate the West. Second, there is a more sober ecclesiastical, political, and intellectual reappraisal of Islamic issues. The author offers a tentative prediction: In a more confrontational environment, the former view will predominate, and vice versa. He then discusses the first component of the dialectic in greater detail over the next three chapters.

In "Circles of Antagonism: Popular Culture," Braibanti states that the negative bias toward Islam and the fear of it are reflected daily in American media and in policy-shaping forums. He cites a few contemporary examples from literature, movies, print media, and documentaries.

He argues that two "subtle rhetorical aberrations" (p. 7) prejudice the perception of Islam. The first one is the term fundamentalist, which is equated with violence. In Christianity, where this term is defined clearly, it refers to a literal interpretation of the Bible by a minority of adherents who believe in biblical infallibility. When this term is applied to Muslims on this basis, virtually all can be called fundamentalists. However, as violence cannot be linked to the quintessentials of Muslim belief, it is unfair to blame all Muslims for the crimes committed by a minority. The author could have elaborated on the nebulousness of this term for Muslims with details like the following: Whereas certain groups of Christians, like the Amish, emulate lifestyles of earlier times in minute details, no "traditional" Muslim spums conclusively the benefits of technetronics. So one would not find a Muslim preferring to travel by camel when motor transport would be affordable and more convenient.

"Fundamentalism" gained currency among Western media with the Iranian revolution of 1979 . Some Muslims often ask: Was this binary opposition, namely, fundamentalist/other, fabricated to sow confusion among Muslims? Would the "other" only refer to a nominal, nonpracticing Muslim? 
The other prejudicial issue outlined is the identification of those engaged in violence by religious affiliation. This applies solely to Muslims. Other culprits are identified by country or ethnicity. He argues succinctly that perpetrators of violence everywhere generally "are a small minority of fanatical individuals whose acts are politically rather than religiously inspired" (p. 9). According to him, only slightly more than 20 percent of terrorist actions between 1990 and 1994 were carried out by Muslims.

In "Circles of Antagonism: The Intellectual Idiom," Braibanti first outlines Huntington's influential paradigm of a Confucian-Islamic threat, with North Korea and China (Confucian) collaborating with Pakistan, Iran, Iraq, Libya, and Algeria (Islamic) against Judaeo-Christianity. He then investigates the relevant views of such social thinkers as Toynbee, Spengler, Berdyaev, Northrop, and Sorokin before presenting deftly his own views as follows: Change is effected by the diffusion of norms from sender to receiver. The greater the technetronic and cybertonic disparities between the two parties, the more successful will be the diffusion. At present, some societies are bewildered at the disparity and try to resist, sometimes violently, such cultural intrusion.

The author distinguishes between culture and civilization. While the latter comprises outward structures, artifacts, and technologies, the former relates to the aesthetic quality or soul of a people. Civilization may be diffused more rapidly than culture, although the two are mutually indistinguishable. As a universal reaction, the culture of a radiating society meets with resistance from a receiving one. All civilizations are constantly evolving, and the author provides insightful examples of this.

Braibanti explains some of the causes of antagonism to the Muslim world during different periods. Superficially, the West observes a lot of violence in contemporary Muslim society, whether related to political problems in the Middle East or elsewhere. The causes of such violence remain uninvestigated, leaving Westerners with feelings of fear and outrage toward Islam. These sentiments are strengthened in those countries where the pro-Israeli lobby is intense. In Europe, the roots of antagonism are mainly demographic: the immigration of laborers from Muslim lands and the higher birth-rate of such domiciled immigrants. Reactions to these Muslims take the form of harassment by states, organizations, or individuals. Within Muslim countries, assistance is often given by Western countries to local unpopular regimes intent upon repressing the legitimate aspirations of the country's citizens. In Britain, anti-Muslim feeling arises from the fear that British culture and institutions are being undermined by foreign immigrants.

Historical reasons for such antipathy include the Crusades of the Middle Ages. There is also the impact of fundamentalist Christianity, which stresses the unique status of Israelites (or modern Israelis) and Zion upon American society. For example, the Israeli annexation of Palestinian lands is seen as the fulfillment of biblical prophecy. While Israelis are elevated, Muslims are subliminally marginalized. 
But there appears to be a gradual improvement in the image of Islam, which is discussed under "Constructive Attitudinal Change." Factors contribution to this are the abandonment by mainline Protestantism, Catholicism, and Orthodoxy of their earlier exclusionary views of other religions, and the increasing sophistication of Muslim and Arab groups in the United States, some of whom have learned to use strategies employed by Jewish groups. This is an important observation. Such an approach is consistent with the outlook of 'Umar ibn al Khattāb, who encouraged the acquisition of Roman and Persian skills for improving administrative efficiency, and with the prophetic dictum: "A wise word is the property of a believer. Wherever he finds it, he is most worthy of it." It is futile for Muslims to continue wallowing in self-pity, for only the finest use of modern technology can be beneficial here.

The author also mentions certain Western articles and publications that have been more objective and the strong Muslim presence in the United States (six hundred mosques serving six million followers). In Western Europe and the Russian Federation, evidence of greater Muslim empathy is based on the greater organizational sophistication of Muslim communities and an increased awareness by non-Muslims of the significance of the global Muslim resurgence. In Britain, Prince Charles's address in 1993 was a milestone, wherein he referred to the contributions that Islam can make to contemporary life. The teaching of the principles of different religions is also mandatory in British schools. In France and elsewhere, government officials are involved in the opening of certain mosques and educational institutions. Some of these structures have been sponsored, either wholly or partly, by Muslim countries. These gestures serve to consolidate diplomatic links with Muslim countries as well as to improve respective state links with Muslim communities in their territories.

In "Structure of the Muslim World," Braibanti notes that the total Muslim population is somewhat above a billion, or roughly 27 percent of the world's population. Its impetus for global expansion is great, particularly with the recovery of an Islamic identity following the post-World War II decolonization and the discovery of massive oil reserves in the Gulf. The resurgence of Islamic activity has occurred at various levels. And yet the concept of an ummah muslimah, the fraternal bond of all Muslims, has seldom been achieved since the Prophet's demise. This is unlikely to change in the foreseeable future, for the ummah is divided along Arab-non-Arab lines. Although Arabs comprise only about 20 percent of the Muslim population, it is evident that, for Arabs, priority is granted to pan-Arabism, as opposed to pan-Islamism, in both theory and practice. Even so, historical events and constant inter-Arab strife have shown pan-Arabism to be illusory. The most prominent example of this is the recent Gulf war. At best, the "Ummah Islamiya can . . . be divided into distinctive regional entities with common problems and, in some cases, cultural affinity" (p. 49).

The most noteworthy circle of the ummah is the Organization of the Islamic Conference (OIC), which consists of fifty-two Muslim countries. 
Complementing its political and diplomatic activities is the Muslim World League. While these groupings can network an Islamic political structure, their infrastructures are loose and lack central authority.

There are also Muslim minorities living under relatively peaceful nonMuslim governments. They make up about one-third of all Muslims. At present, there are about 18 million Muslim refugees who have fled unfriendly regimes (i.e., Afghanistan, Palestine, Bosnia) but who have not established a permanent or semipermanent home in their new homelands.

Within this ummah lies great cultural diversity, ranging from relative pristinity in Saudi Arabia (which has remained largely immune to external cultural influences) to hybridization in Egypt and Indonesia. In the latter, colonial rule and preexisting cultures have influenced Muslim societies.

Braibanti finds sectarian divisions here less pronounced and fewer than those in Christianity. He prefers the term modalities to sects when referring to Muslims. Thereafter, he details the major division (Sunni/Shi'i) and provides subdivisions of the latter. Presently, he concludes, it is the Shi' $i$ Iranian government, with its growing military and nuclear capabilities, that concerns other Muslim regimes and some Western countries. Other divisive factors are ethnographic and linguistic diversities of which four examples are discussed: Berbers, Kurds, Tartars, and Kashmiris.

After a brief examination of the negative impact of dominant culture on minority Muslims, Braibanti shifts his attention to non-Muslim minorities in Muslim countries. The spotlight falls on the wide range of freedom of worship available to such people. Christians are a numerically significant minority in Muslim countries and particularly in the Middle East. There are likewise great differences in state polity. Political concepts and systems vary considerably, depending upon the nature and extent of influences from colonial or postcolonial sources. The author provides appropriate examples of all categories.

Finally, he analyzes religious complementarities among the three Abrahamic faiths. Apart from scriptural examples, he cites some practical experiences of Muslim-Christian relations during this decade. JewishMuslim reconciliation is urgently needed; relations deteriorated mainly after the vigorous Zionist campaigns for the establishment of Israel.

In "Conspectus," the author summarizes the arguments raised earlier and concludes some of them with additional insights. Among them is the "green menace," which poses only problems for such unacceptable Muslim governments as those in Egypt, Algeria, and Saudi Arabia (his inclusion of Sudan in this category is surprising, since it is populist). Their failure to uphold civil liberties has rendered them illegitimate in the eyes of their citizens. When such regimes are aided by foreign powers, the problems become internationalized. The author rightly advises the West to abstain from meddling in Muslim nations' internal political affairs-perhaps he could have urged them to assist actively the promotion of justice in those same countries-and justifiably warns the West not to practice selective morality by ignoring human rights violations in Bosnia, Chechnya, and Kashmir. 
The greatest challenge for Muslims is both to maintain and radiate their beliefs in a predominantly non-Islamic world order. Moreover, this task has to be fulfilled while they are in an inferior position. A possible solution lies in the mustering of all resources of ijtihad. In addition, imaginative leadership is needed to galvanize the Muslims into a viable ummah, to spum violence by minority groups, and to outgrow dependence upon the technetronic skills of non-Muslims. If the piety and dynamism of Islam could be conveyed to the West, the latter would be rescued from its current morbidity. For this, Muslims must be prepared to apply the Islamic principles of peace, justice, and reverence for life.

The spectrum of contemporary Muslim society covered by this book is impressive, although the discussion might appear somewhat brief at times. It contains a convincing blend of theory and applications and certainly fulfills the requirements of a position paper on this topic from a phenomenological perspective. At the same time, the style is lucid, concise, and objective, thereby making the discussion compelling reading.

Yousuf Dadoo Sub-department of Arabic and Islamic Studies Deparment of Semitics University of South Africa 